\title{
Chimeric Antigen Receptor T-cells
}

National Cancer Institute

\section{Source}

National Cancer Institute. Chimeric Antigen Receptor T-cells. NCI Thesaurus. Code C137999.

Autologous or allogeneic T-lymphocytes that are eng ineered to contain a chimeric antigen receptor (CAR) that specifically targ ets a particular antigen. 